\title{
Pulmonary delivery of the broad-spectrum matrix metalloproteinase inhibitor marimastat diminishes multiwalled carbon nanotube-induced circulating bioactivity without reducing pulmonary inflammation
}

\author{
Tamara L. Young ${ }^{1}$, Ekaterina Mostovenko², Jesse L. Denson ${ }^{1}$, Jessica G. Begay ${ }^{1}$, Selita N. Lucas', \\ Guy Herbert ${ }^{1}$, Katherine Zychowski ${ }^{3}$, Russell Hunter ${ }^{1}$, Raul Salazar ${ }^{1}$, Ting Wang ${ }^{4}$, Kelly Fraser ${ }^{5}$, Aaron Erdely ${ }^{5}$, \\ Andrew K. Ottens ${ }^{2}$ and Matthew J. Campen ${ }^{1^{*} \text { (i) }}$
}

\begin{abstract}
Background: Multiwalled carbon nanotubes (MWCNT) are an increasingly utilized engineered nanomaterial that pose the potential for significant risk of exposure-related health outcomes. The mechanism(s) underlying MWCNTinduced toxicity to extrapulmonary sites are still being defined. MWCNT-induced serum-borne bioactivity appears to dysregulate systemic endothelial cell function. The serum compositional changes after MWCNT exposure have been identified as a surge of fragmented endogenous peptides, likely derived from matrix metalloproteinase (MMP) activity. In the present study, we utilize a broad-spectrum MMP inhibitor, Marimastat, along with a previously described oropharyngeal aspiration model of MWCNT administration to investigate the role of MMPs in MWCNT-derived serum peptide generation and endothelial bioactivity.
\end{abstract}

Results: C57BL/6 mice were treated with Marimastat or vehicle by oropharyngeal aspiration $1 \mathrm{~h}$ prior to MWCNT treatment. Pulmonary neutrophil infiltration and total bronchoalveolar lavage fluid protein increased independent of MMP blockade. The lung cytokine profile similarly increased following MWCNT exposure for major inflammatory markers (IL-1 $\beta, I L-6$, and TNF-a), with minimal impact from MMP inhibition. However, serum peptidomic analysis revealed differential peptide compositional profiles, with MMP blockade abrogating MWCNT-derived serum peptide fragments. The serum, in turn, exhibited differential potency in terms of inflammatory bioactivity when incubated with primary murine cerebrovascular endothelial cells. Serum from MWCNT-treated mice led to inflammatory responses in endothelial cells that were significantly blunted with serum from Marimastat-treated mice.

Conclusions: Thus, MWCNT exposure induced pulmonary inflammation that was largely independent of MMP activity but generated circulating bioactive peptides through predominantly MMP-dependent pathways. This MWCNT-induced lung-derived bioactivity caused pathological consequences of endothelial inflammation and barrier disruption.

*Correspondence: MCampen@salud.unm.edu

1 Department of Pharmaceutical Sciences, MSC09 5360, 1 University

of New Mexico, Albuquerque, NM 87131-0001, USA

Full list of author information is available at the end of the article

(c) The Author(s) 2021. Open Access This article is licensed under a Creative Commons Attribution 4.0 International License, which permits use, sharing, adaptation, distribution and reproduction in any medium or format, as long as you give appropriate credit to the original author(s) and the source, provide a link to the Creative Commons licence, and indicate if changes were made. The images or other third party material in this article are included in the article's Creative Commons licence, unless indicated otherwise in a credit line to the material. If material is not included in the article's Creative Commons licence and your intended use is not permitted by statutory regulation or exceeds the permitted use, you will need to obtain permission directly from the copyright holder. To view a copy of this licence, visit http://creativecommons.org/licenses/by/4.0/. The Creative Commons Public Domain Dedication waiver (http://creativeco mmons.org/publicdomain/zero/1.0/) applies to the data made available in this article, unless otherwise stated in a credit line to the data. 
Keywords: Multiwall carbon nanotube (MWCNT), Carbon nanotubes, Nanoparticles, Nanomaterials, Matrix metalloproteinase, Inflammation, Serum-bioactivity, Biomarker

\section{Introduction}

Engineered nanomaterials (ENM; materials with at least one dimension $<100 \mathrm{~nm}$ ) represent one of the fastest growing sources of technological advances over the last two decades. Significant government and private investments to the tune of an estimated US $\$ 8.5$ billion global market value was reported in 2019 and this is expected to reach US\$9.6 billion in 2020 [1]. Optimism for the future of ENM application is tempered by concerns regarding both potential human health effects and environmental impacts of production and use [1-6]. Carbon nanotubes (CNT), consisting of singlewalled (SWCNT) and multi-walled (MWCNT) varieties, represent one of the fastest growing ENM fields. The unique physical, chemical, and electrical properties make CNT suitable for a wide range of applications and accounts for their popularity $[7,8]$. As the body of literature around CNT toxicity increases, common findings of inhalation exposure to CNT include disruption of lung tissue architecture, recruitment of inflammatory cells and activation of inflammatory responses [9-13].

The extracellular matrix (ECM), which plays a significant role in these processes, is a complex dynamic structure ubiquitous in all tissues and is in a perpetual state of controlled degradation and regeneration [14]. Uncontrolled degradation of the ECM can lead to homeostatic dysregulation and pathologic transformation. The process of ECM turnover is facilitated mainly by matrix metalloproteinases (MMPs), a large family of zinc-dependent endopeptidases [15-17]. ECM degradation generates bioactive peptide fragments termed "matrikines" that function in a wide array of biological processes to facilitate tissue homeostasis, signal transduction and wound healing [18]. Within the lung, ECM degradation products have been implicated in pathologic processes leading to fibrotic transformation and chronic obstructive pulmonary disease (COPD) [19]. The tripeptide fragment pro-gly-pro (PGP), an ECM collagen derived neutrophil chemokine containing sequences similar to those that bind the CXCR $1 / 2$ receptors [20], has been proposed as a biomarker in COPD and in cystic fibrosis pathogenesis [21, 22]. PGP is generated in a feedback loop following MMP-8 and MMP-9 activation and is implicated in sustained neutrophilic inflammation [22-25].

We previously demonstrated a link between ENM exposure, specifically MWCNT, and MMP activity. Wild-type mice exposed to MWCNT exhibited serum bioactivity that led to dysregulated endothelial function in treated vessels ex vivo; this bioactivity was largely absent in serum from MMP-9 knockout mice exposed to MWCNT [26]. Serum from thrombospondin (TSP), a matrix glycoprotein and MMP-9 substrate, knockout animals failed to impair vasodilation in naive vessels [27]. As we recently demonstrated, MWCNT exposure produced serum bioactivity that resulted in blood-brain barrier disruption and neuroinflammatory activation; a TSP peptide fragment was a key player in this outcome [28]. These findings collectively implicate proteinase activity in the lung as an indirect driver of systemic vascular outcomes. The specific mechanisms underlying pulmonary-derived serum bioactivity is still unclear. However, serum peptidomic analysis indicated significantly increased lung protease expression, including overlapping and independent peptide profiles between the lung and systemic circulation [29]. These peptide profiles included significant changes in MMP substrates with functionality in ECM organization, inflammation, cardiovascular pathology, cell receptor signaling and exosome components [29]. Understanding the role of MMPs in generating ECM-derived matrikines (and many other peptide fragments) may represent novel biomarkers of exposure-and potentially drivers of morbidity-not previously explored. In this study, we investigated the role of MMPs in MWCNT-exposure derived serum bioactivity by utilizing a broad-spectrum MMP inhibitor delivered selectively to the lung.

\section{Methods \\ Animals and exposures}

Specific pathogen-free 6-8-week-old male C57BL/6J mice (Jackson Laboratory) were used in this study. Animals were housed in an Association for Assessment and Accreditation of Lab Animal Care Internationalapproved animal facility at the University of New Mexico with procedures approved by Institutional Animal Care and Use Committee of the University of New Mexico. Animal care and use procedures were conducted in accordance with the US Public Health Service's Policy on Humane Care and Use of Laboratory Animals (https://grants.nih.gov/grants/olaw/references/phspol. htm) and the National Institutes of Health's Guide for the Care and Use of Laboratory Animals (https://grants. nih.gov/grants/olaw/Guide-for-the-Care-and-Use-ofLaboratory-Animals.pdf). Normal chow and water were 
provided ad libitum in ventilated cages in a temperatureand humidity-controlled environment with a 12-h light/ dark cycle.

The C57BL/6 J mice were randomized into six groups and treated via oropharyngeal aspiration under light isoflurane anesthesia. A broad-spectrum matrix metalloproteinase (MMP) inhibitor, Marimastat (Alfa AesarJ67288) dissolved in 1\% Dimethyl Sulfoxide (DMSO) at a final concentration of $10 \mathrm{mg} / \mathrm{kg}$ of body weight, or $1 \%$ DMSO in $1 \times$ phosphate buffered saline (PBS; Fig. 1) was administered to half of the animals $1 \mathrm{~h}(\mathrm{~h})$ prior to exposure to multiwalled carbon nanotubes (MWCNT). MWCNTs were prepared in dispersion media (DM) consisting of mouse serum albumin $(0.6 \mathrm{mg} / \mathrm{mL})$ and 1,2-dipalmitoyl-sn-glycero-3-phosphocholine $\quad(10 \mu \mathrm{g} /$ $\mathrm{mL}$ ), sonicated prior to administration and vortexed between each animal dosed. The MWCNT material used in this study, MWCNT-7, has been extensively characterized [30-34]. MWCNT were examined by transmission electron microscopy (TEM) on a JEOL2100F TEM (JEOL USA, Inc., Peabody, MA, USA) using the modified NMAM for CNT on MCE Filters by TEM as previously described [34,35]. The average diameter between studies ranges from 49 to $63 \mathrm{~nm}$ with an average length around $4 \mu \mathrm{m}$ (Fig. 2). Purity was $>99 \%$ carbon. MWCNT was administered at doses of $0 \mu \mathrm{g}$ (DM only), $10 \mu \mathrm{g}$ or $40 \mu \mathrm{g}$ MWCNT suspended in $50 \mu \mathrm{l}$ volume $(\mathrm{n}=5 / \mathrm{grp})$ (Fig. 1); doses were based on prior findings $[26,29]$ to

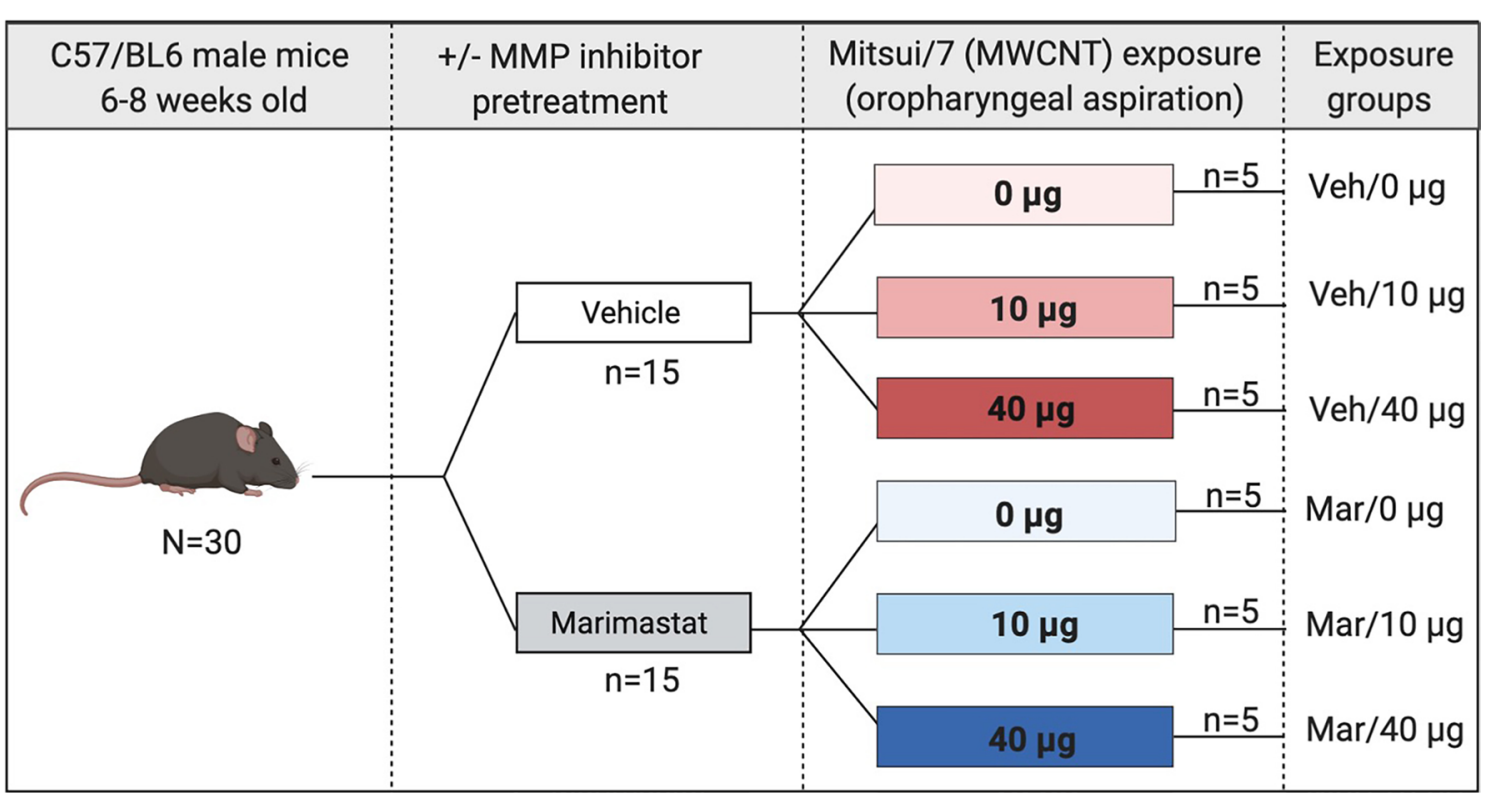

Fig. 1 Experimental Design. Male C57BL/6 mice aged 6-8 weeks were randomized into 6 groups of 5 mice each. Animals were weighed and dosed with $10 \mathrm{mg} / \mathrm{kg}$ body weight Marimastat via oropharyngeal aspiration $1 \mathrm{~h}$ prior to dosing with dispersion media (DM; $0 \mu \mathrm{g}), 10 \mu \mathrm{g}$, or $40 \mu \mathrm{g}$ of MWCNT via oropharyngeal aspiration. Animals were euthanized 24-h post MWCNT exposure and tissues collected to assess pulmonary inflammation, serum peptide profile and serum bioactivity. (Figure generated in BioRender)

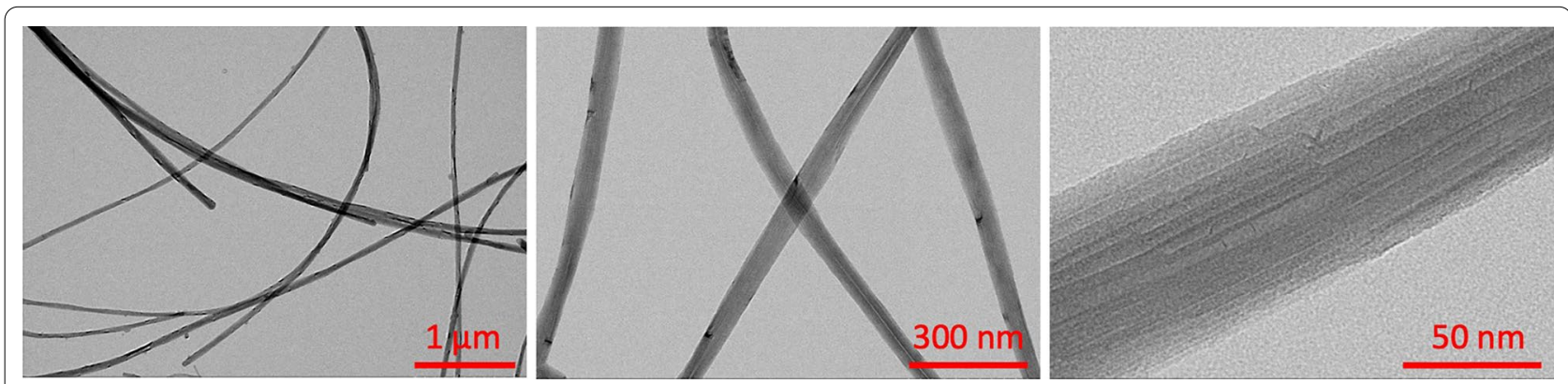

Fig. 2 Electron microscopy images of the Mitsui-7 MWCNT used for this study, at increasing magnification 
permit the current mechanistic follow up study. Mice were euthanized at $24 \mathrm{~h}$ following MWCNT pulmonary dosing using isoflurane and exsanguination. At the time of euthanasia, blood and bronchoalveolar lavage fluid (BALF) were collected; blood was allowed to clot on ice and then centrifuged to collect serum. Following transcardial perfusion with ice-cold $1 \times$ PBS, lavaged lungs and heart were collected and flash frozen in liquid nitrogen for later determination of changes in relative mRNA expression.

\section{Pulmonary inflammation assessment Bronchoalveolar lavage fluid (BALF) Cell composition}

Lung lavage fluid was collected by instilling $1 \mathrm{~mL}$ of sterile PBS and immediately withdrawing fluid twice via cannulated trachea. Cell counts were determined by centrifuging BALF, less $200 \mu \mathrm{L}$, at $1800 \times g$ for $5 \mathrm{~min}$ to form a cell pellet. The pellet was re-suspended, stained with trypan blue for a viable cell count with a hemocytometer. Cells were seeded at 10,000 cells/slide and the total cells were manually counted under a light microscope. Differential BALF cell counts were assessed by centrifuging $200 \mu \mathrm{L}$ of BALF onto a cytospin slide preparation and the number of polymorphonuclear neutrophils and macrophages quantified using HEMA3 stain (Protocol, Thermo Fisher Scientific).

\section{BALF cytokine levels}

MWCNT-induced cytokine protein changes in BALF were determined using electrochemiluminescence. The Meso Scale Discovery MULTI-SPOT V-PLEX ${ }^{\circledR}$ Cytokine Assay System Proinflammatory Panel 1 (mouse) kit (K15048D-Meso Scale Diagnostics LLC, Rockville, $\mathrm{MD}$ ) was used according to manufacturer's instructions. Briefly, $50 \mu \mathrm{L} /$ well of the BALF supernatant were loaded onto sample plates pre-coated with capture antibodies for the following cytokines: IL-1 $\beta$ (interleukin 1 beta), IL-2 (interleukin 2), IL-4 (interleukin 4), IL-5 (interleukin 5), IL-6 (interleukin 6), IL-10 (interleukin 10), IL-12p70 (interleukin 12 active heterodimer), IFN- $\gamma$ (interferon gamma), TNF- $\alpha$ (tumor necrosis factor alpha) and $\mathrm{KC} /$ GRO (CXCL1, chemokine C-X-C motif ligand 1). Plates were incubated with gentle shaking for $2 \mathrm{~h}$ at room temperature. Plates were washed $3 \times$ with buffer containing $1 \times$ PBS and $0.05 \%$ Tween 20 . Detection antibody was added to each well and allowed to react for $1 \mathrm{~h}$ at room temperature under gentle shaking. Plates were washed as above, and Read Buffer was added to each well. Plates were analyzed on an MSD QuickPlex SQ 120 instrument (MSD, AI0AA-0); Discovery Workbench (v. 4.0) software calculated cytokine concentrations using a linear regression analysis of the standard curve. All concentrations were normalized to total BALF protein, determined using a standard Bradford protein assay.

\section{Whole lung cytokine gene expression analysis}

Flash frozen lung tissue was homogenized in lysis buffer (Buffer RLT) and total RNA was isolated according to the RNeasy Mini Kit (QIAGEN, Germantown, MD) protocol. RNA $(1 \mu \mathrm{g})$ was reverse transcribed using High-Capacity cDNA Reverse Transcription Kit (Applied Biosystems; 4368814) in a thermal cycler under the following conditions: Step 1: $25{ }^{\circ} \mathrm{C}$ for $10 \mathrm{~min}$; Step 2: $37{ }^{\circ} \mathrm{C}$ for $120 \mathrm{~min}$; Step 3: $85^{\circ} \mathrm{C}$ for $5 \mathrm{~min}$; and Step 4: $4{ }^{\circ} \mathrm{C}$ for infinity. Generated cDNA (50 ng) was used to assess gene expression changes via quantitative realtime PCR (qPCR) in a 96-well format. Expression of murine Il1 $\beta$ (Interleukin 1 beta; Mm00434228_m1), Il6 (Interleukin 6; Mm00446190-m1), Ccl2 (C-C Motif Chemokine Ligand-2; Mm00441242_m1), Tgfb (Transforming growth factor beta 1; Mm01178820_m1), Tnfo (Tumor necrosis factor alpha; Mm00443258_m1), Icam1 (Intercellular adhesion molecule 1; Mm00516023 $\mathrm{m} 1$ ), and Vcam1 (Vascular cell adhesion molecule 1; Mm01320970_m1) (Applied Biosystems, Foster City, CA) were measured using the TaqManR Gene Expression protocol (ThermoScientific, Waltham, MA) following the manufacturer's instructions. Relative gene expression normalized to the housekeeping gene TATA-Box Binding Protein (tbp; Mm00446973_m1) was determined using the $2^{-\Delta \Delta C T}$ method for all samples with threshold cycle values (CT) under 35 . Results are expressed as fold change.

\section{Serum peptidomic mass spectrometry}

Endogenous peptidomic analysis was performed on mouse serum specimens collected following treatment with $0 \mu \mathrm{g}, 10 \mu \mathrm{g}$ or $40 \mu \mathrm{g}$ of MWCNT, with and without Marimastat pretreatment ( $\mathrm{n}=5 / \mathrm{grp}$ ) using previously described methodology [29]. Briefly, $40 \mu \mathrm{L}$ of serum was pre-filtered using a $0.22 \mu \mathrm{m}$ Ultrafree-MC unit (Millipore) using the manufacturer's instructions. Samples were reduced in $18 \mathrm{mM}$ TCEP and denatured in $20 \%$ acetonitrile and thiol-protection with $30 \mathrm{mM}$ iodoacetamide to dissociate peptide content from carrier moieties. Samples were size-fractionated using YM-30 MicroCon units (Millipore) per manufacturer's instructions with an effective mass cutoff of approximately $8 \mathrm{kDa}$. The retentate was further dissociated by acidification with $0.4 \%$ formic acid to disrupt ionic interactions and re-spun through the YM-30 to combine filtrates. The filtrate was de-salted, de-lipidated and concentrated by solid-phase extraction using a Symmetry C18 reversed-phase column (Waters). The enriched peptide samples $(4 \mu \mathrm{L})$ were then gradient separated (6-44\% acetonitrile in $0.1 \%$ formic acid) using 
a $150 \mathrm{~mm} \times 75 \mu \mathrm{m}$ HSS T3 reversed-phase capillary column on a NanoAcquity UPLC online with a Waters Synapt G2-Si tandem mass spectrometer (Waters). The instrument was operated in UDMSe mode [36] for dataindependent analysis at 25,000 resolving power and the quadrupole optimized to exclude small-molecule ions below $500 \mathrm{~m} / \mathrm{z}$. UDMSe data were peak picked 150 and 50 ion count thresholds for low-energy and high-energy scans, respectively, and deisotoped using ProteinLynx Global SERVER $^{\mathrm{TM}}$ (PLGS) software v3.0.3 (Waters). Resultant ion tables were aligned across replicates by retention time ( $\pm 1.5 \mathrm{~min}$ ), drift time ( \pm 5 bins) and accurate mass $( \pm 12 \mathrm{ppm})$ measures with EndogeSeq (https:// ottenslab.weebly.com/endogeseq.html). Precursor ion tables were then filtered to retain only highly reproducible measures $(n \geq 4 /$ grp $)$, with matched product ions $( \pm 24 \mathrm{ppm})$ retained if present in at least two biological replicates. Left censored data were imputed by randomgenerated value sets centered at the limit of quantification accounting for the datasets median ion variance and missingness across replicates [37]. The compiled peptidomic data were median centered and $\log _{2}$ transformed before testing for effects of MWCNT exposure, Marimastat pretreatment or their interaction using 2-way Analysis of Variance (ANOVA) and Benjamini-Hochberg multiple-measures correction in Multiple Experiment Viewer (mev.tm4.org), set to a 5\% false discovery rate.

\section{Serum cumulative inflammatory potential assay}

Mouse cerebrovascular endothelial cells (mCECs) were obtained from a commercial vendor (Cell Biologics, Chicago, IL) and maintained according to manufacturer's recommendations at $37{ }^{\circ} \mathrm{C}$ and $5 \% \mathrm{CO}_{2}$ with complete endothelial cell medium supplemented with $5 \%$ fetal bovine serum. All experiments were conducted with cells between passages 3 and 8 . To determine the serum cumulative inflammatory potential of MWCNT exposure, mCECs were treated with serum isolated from exposed or control C57BL/6 male mice as previously described [38, 39]. Briefly, mCECs were serum starved overnight then incubated in FBS-free culture media supplemented at a final concentration of $5 \% \mathrm{v} / \mathrm{v}$ serum from dispersion media control $(0 \mu \mathrm{g}$; DM), $10 \mu \mathrm{g}$, or $40 \mu \mathrm{g}$ MWCNT-exposed mice for $4 \mathrm{~h}$. RNA was isolated from treated mCECs using the RNeasy Mini Kit (QIAGEN, Germantown, MD), and $1 \mu \mathrm{g}$ was reverse transcribed prior to gene expression analyses via quantitative realtime PCR (qPCR). Furthermore, in an additional permutation, cells were pretreated with either non-immune IgG or a cluster of differentiation 36 (CD36) neutralizing antibody to test the role of CD36 in mediating responses $(1 \mu \mathrm{g} / \mathrm{mL}, 30 \mathrm{~min}$ prior to serum). Expression of mouse
Ccl2, Il6, Tgf- $\beta$, Icam1, and Vcam1 were measured, as described above. Relative gene expression, normalized to the housekeeping gene Tbp was determined using the $2^{-\Delta \Delta C T}$ method for all samples with cycle threshold (CT) values under 35 . Results are expressed as fold change.

\section{Monolayer impedance-based quantification of cell growth and barrier integrity}

Electric Cell-substrate Impedance Sensing (ECIS; Applied Biophysics) system was used to evaluate endothelial barrier integrity changes of $\mathrm{mCECs}$ in a monolayer following exposure to serum from DM- or MWCNT-exposed mice. Briefly, cells were grown in ECIS culture chambers on top of an opposing circular gold electrode array. A constant small alternating current was applied between the electrodes and the changes in electrical potential across the monolayer was measured and resistance changes were recorded every minute. mCECs were allowed to come to confluence, then serum-starved overnight. The following day, serum-free culture media was supplemented with serum from DM- or MWCNT-exposed mice at a concentration of $5 \% \mathrm{v} / \mathrm{v}$. The cells were then incubated at $37^{\circ} \mathrm{C}$ and $5 \% \mathrm{CO}_{2}$ for $4 \mathrm{~h}$. Baseline serum-response readings were captured over this period and then an electric current was passed through the gold electrode to disrupt the confluent cell layer ("wounding"). The rate of recovery from wounding was evaluated by assessing the length of time for resistance readings to return to the pre-wounding baselines.

\section{Statistics}

All statistics were conducted in GraphPad Prism (v9.0). Data were tested for Guassian normality using a Shapiro-Wilk test; most data sets were observed ot be normal. The infrequent nature of non-Guassian distribution of data led to the choice of standard parametric statistical tests for all assays. Data were either assessed as a 2-way ANOVA, considering MWCNT and Marimastat treatments as the 2 factors. Tukey's post-hoc multiple comparison test was used when appropriate. For serum cumulative inflammatory potential assays, a 3-way ANOVA was conducted, including the use of IgG vs CD36 antibody treatment.

\section{Results}

\section{Pulmonary inflammation}

\section{BALF inflammatory cell profile}

MWCNT-exposure drives lung inflammation via mechanisms that are predominantly independent of MMP activation. MWCNT-induced pulmonary inflammation was assessed by total protein and differential cell counts from bronchoalveolar lavage fluid (BALF) collected from DM- and Marimastat-pretreated, 

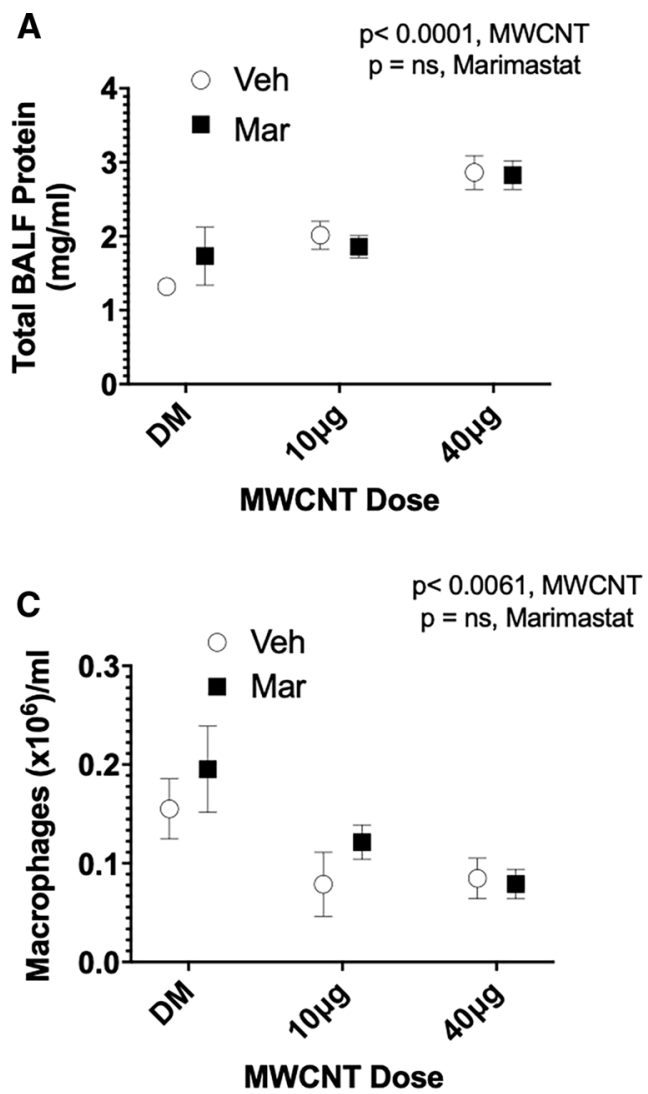
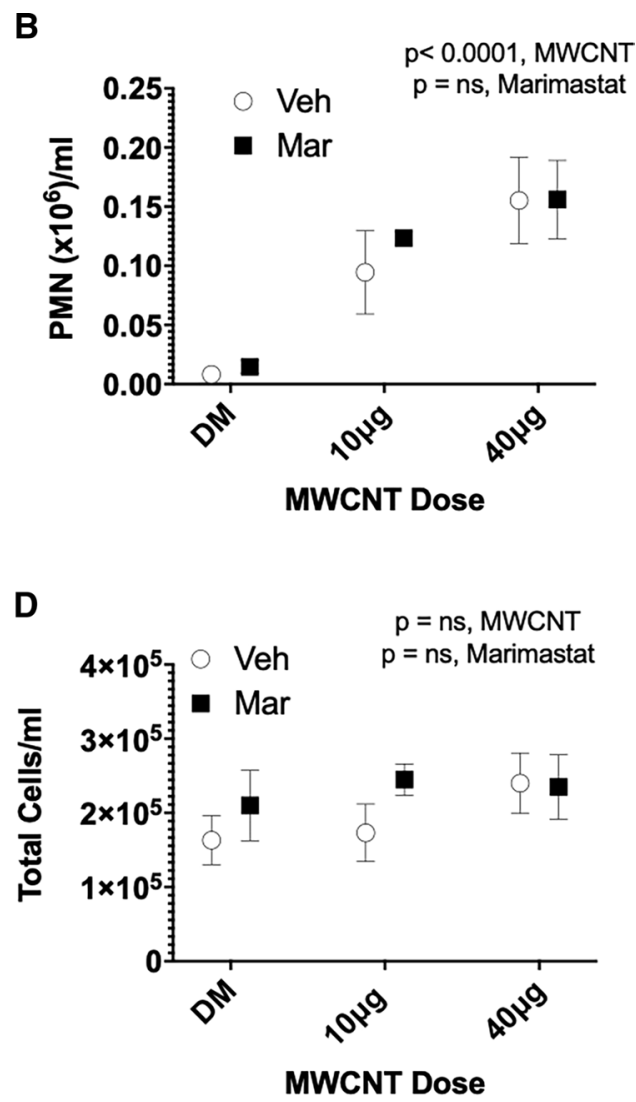

Fig. 3 MWCNT-mediated lung inflammation. Bronchoalveolar lavage fluid (BALF) total protein and infiltrating inflammatory cell count. MWCNT exposure-induced pulmonary inflammation was not altered by MMP blockade. a Total lavage fluid protein concentration assessed via Bradford protein assay. MWCNT-exposure increased BALF total protein in a dose-dependent manner when compared with controls. $\mathbf{b}$ and $\mathbf{c}$ BALF cell differentials; Polymorphonuclear neutrophils (PMN) cells were significantly increased by MWCNT exposure at both low and high doses; Macrophages in BALF were decreased in MWCNT treated cells. d Total BALF cells were unchanged by MWCNT exposure. $p$ values based on 2-way ANOVA presented for each figure. $\mathrm{N}=4-5$ per group. Data presented are means \pm SEM

MWCNT-exposed mice. MWCNT induced a significant $(p<0.0001)$ dose-dependent increase in BALF total protein (Fig. 3a). Accompanying this increase was a significant influx of polymorphonuclear neutrophils (Fig. 3b). A modest reduction of macrophages was also observed (Fig. 3c), but overall, the total cell counts were stable, if not increasing in the MWCNT-exposed mice (Fig. 3d). These indicators of lung inflammatory activation occurred via mechanisms independent of MMP activity, as Marimastat pretreatment did not alter MWCNT-mediated responses.

\section{BALF cytokine expression}

To further investigate the role of MWCNT in the lung, we assessed cytokines in the BALF using a multiplex electrochemiluminescence assay. Most conventional inflammatory cytokines (IL-1 $\beta$, IL-2, IL-4, IL-6, TNF- $\alpha$, and $\mathrm{KC}-\mathrm{GRO}$ ) (Fig. 4a-c, e, i, j) increased in response to MWCNT treatment and were not affected by MMP inhibition. Some cytokines remained unchanged by MWCNT treatment or MMP blockade (IL-10, IL12p70 and IFNץ; Fig. $4 \mathrm{f}-\mathrm{h}$ ). Interestingly, IL-5 did show inhibition of MWCNT-mediated induction by Marimastat

(See figure on next page.)

Fig. 4 MWCNT-mediated pulmonary inflammatory activation. Bronchoalveolar lavage fluid (BALF) inflammatory cytokine profile assessed via Meso Scale Discovery multiplex cytokine assay. MWCNT-exposure increased BALF cytokine protein expression in a dose-dependent manner which was not significantly altered by MMP blockade. a IL-1 $\beta$ cytokine protein expression. $\mathbf{b} \| \mathrm{L}-2$ cytokine protein expression. $\mathbf{c} I L-4$ cytokine protein expression. d IL-5 cytokine protein expression. e IL-6 cytokine protein expression. $\mathbf{f}$ IL-10 cytokine protein expression. $\mathbf{g}$ IL $12 \mathrm{p} 70$ cytokine protein expression. $\mathbf{h}$ IFN- $\gamma$ cytokine protein expression. i TNF-a cytokine protein expression. $\mathbf{j}$ KC-Gro/CXCL1/GROa chemokine protein expression. $p$ values based on 2-way ANOVA presented for each figure. $\mathrm{N}=4-5$ per group. Data presented are means \pm SEM 



Fig. 4 (See legend on previous page.) 
(Fig. 4d) and IL-12p70 was just outside the range of significance $(p=0.054)$ for an MMP inhibition effect (Fig. 4g). These outcomes suggest that certain cytokine induction may be downstream of inflammatory MMP induction, though most are not.

\section{Whole lung cytokine gene expression}

Finally, we examined pulmonary inflammation in terms of transcriptional changes in whole lung homogenates. Most cytokine gene expression trends were consistent with protein levels in BALF, with $I l 1 \beta, I l 6, C c l 2$, Tnfo and Vcam1 (Fig. 5a-c, e and g) increasing in a dose-dependent manner following MWCNT treatment. Apart from Tnfo, which showed significant decrease at bot doses of MWCNT, this increase was unaltered by MMP inhibition. We additionally tested Icam1 mRNA (Fig. 5f) expression as a marker of vascular injury and it showed a non-significant elevation following MWCNT exposure. Combined with BALF findings, these data show pulmonary inflammation due to MWCNT exposure is only minimally influenced by local MMP activity. Neither MWCNT nor Marimastat treatment altered Tgf $\beta$ expression (Fig. 5d).

\section{MWCNT- and MMP-blockade induced serum peptide changes}

Consistent with recent studies of serum peptidomic changes after MWCNT exposure [29, 40], the $10 \mu \mathrm{g}$ and $40 \mu \mathrm{g}$ doses of MWCNT led to substantial generation of numerous circulating peptide fragments ( $<8 \mathrm{kDa}$ cutoff). Both doses of MWCNT produced clustering of common elevated peptides (Fig. 6, purple box), as well as induction of unique dose specific peptides (Fig. 6, $10 \mu \mathrm{g}$; red box, $40 \mu \mathrm{g}$; blue box); findings appeared consistent with more extensive characterizations of this exposure [28, 29, 41]. Importantly, pulmonary Marimastat pretreatment returned serum peptidomic profiles to near control levels by almost completely abolishing those induced peptides. Given the distinct observable changes in serum peptide profile following targeted pulmonary MMP blockade, these findings strongly suggest the serum peptides originated from MMP activation and activity in the lung following MWCNT exposure.
Serum cumulative inflammatory potential assessment To determine the inflammatory bioactivity of the serum following MWCNT dosing and Marimastat pretreatment, serum $(5 \% \mathrm{v} / \mathrm{v})$ from control and exposed mice was added to confluent mCECs for $4 \mathrm{~h}$, followed by qPCR assessment of canonical inflammatory response genes from the mCECs including Ccl2, Il6, Tgfb, Icam1, and Vcam1 (Fig. 7). Additionally, since previous studies showed a potential role for CD36 in mediating seruminduced vascular reactivity changes [26], we assessed its role in vitro using an anti-CD36 antibody compared to a non-immune immunoglobulin G (IgG) control pretreatment. Three-way ANOVA analyses were therefore used to test independent or interactive roles of MWCNT, Marimastat, and CD36. MWCNT serum exposure resulted in significant upregulation of endothelial $\mathrm{Ccl} 2$ and Vcam1 mRNA $(p<0.0001)$ in both IgG and CD36 antibody treatment groups. $C c l 2$ expression was reduced in the CD36 ab+Marimastat group, based on significant interaction terms in the 3-way ANOVA $(p<0.05)$. $V$ cam1 expression, also significantly induced $(p<0.0001)$ by MWCNT-treated serum, was not upregulated in serum from mice treated with MWCNT and Marimastat $(p=0.044)$. Icam 1 gene expression was increased by serum from MWCNT-treated mice $(p=0.0216)$ with an apparent abrogation of this effect by Marimastat (Fig. 7d).

\section{Functional assessment of MWCNT-mediated serum bioactivity}

To assess the functional consequences of the MWCNTgenerated serum bioactivity, serum from exposed mice was used to assess endothelial barrier integrity changes in an endothelial monolayer using the ECIS assay (Fig. 8). Following treatment with serum from control $(\mathrm{DM}+$ Vehicle and $\mathrm{DM}+$ Marimastat $)$ mice, mCEC monolayer resistance increased after a brief decline, to $\sim 110 \%$ of baseline after $1 \mathrm{~h}$ and then again to $\sim 135 \%$ of baseline after $15 \mathrm{~h}$. Treatment with serum from $40 \mu \mathrm{g} /$ Veh-treated mice significantly reduced barrier integrity acutely and continuously for the $\sim 20 \mathrm{~h}$ assay, to approximately $70-80 \%$ of baseline levels. Serum from mice treated with MWCNT + Marimastat also decreased integrity initially, but cells appeared to recover more quickly than cells exposed to serum from MWCNT treatment alone, although recovery was not fully back

(See figure on next page.)

Fig. 5 Lung cytokine gene expression profile. Cytokine expression in response to MWCNT was largely unaltered by lung MMP blockade. a //16 gene expression. b //6 gene expression. c C 12 gene expression. d Tgfb gene expression. e Thfa gene expression. f /cam 1 gene expression. $\mathbf{g}$ Vcam 1 gene expression. Marimistat only inhibited Tnfa expression (e). $p$ values based on 2-way ANOVA presented for each figure. N=4-5 per group. Data presented are means \pm SEM 

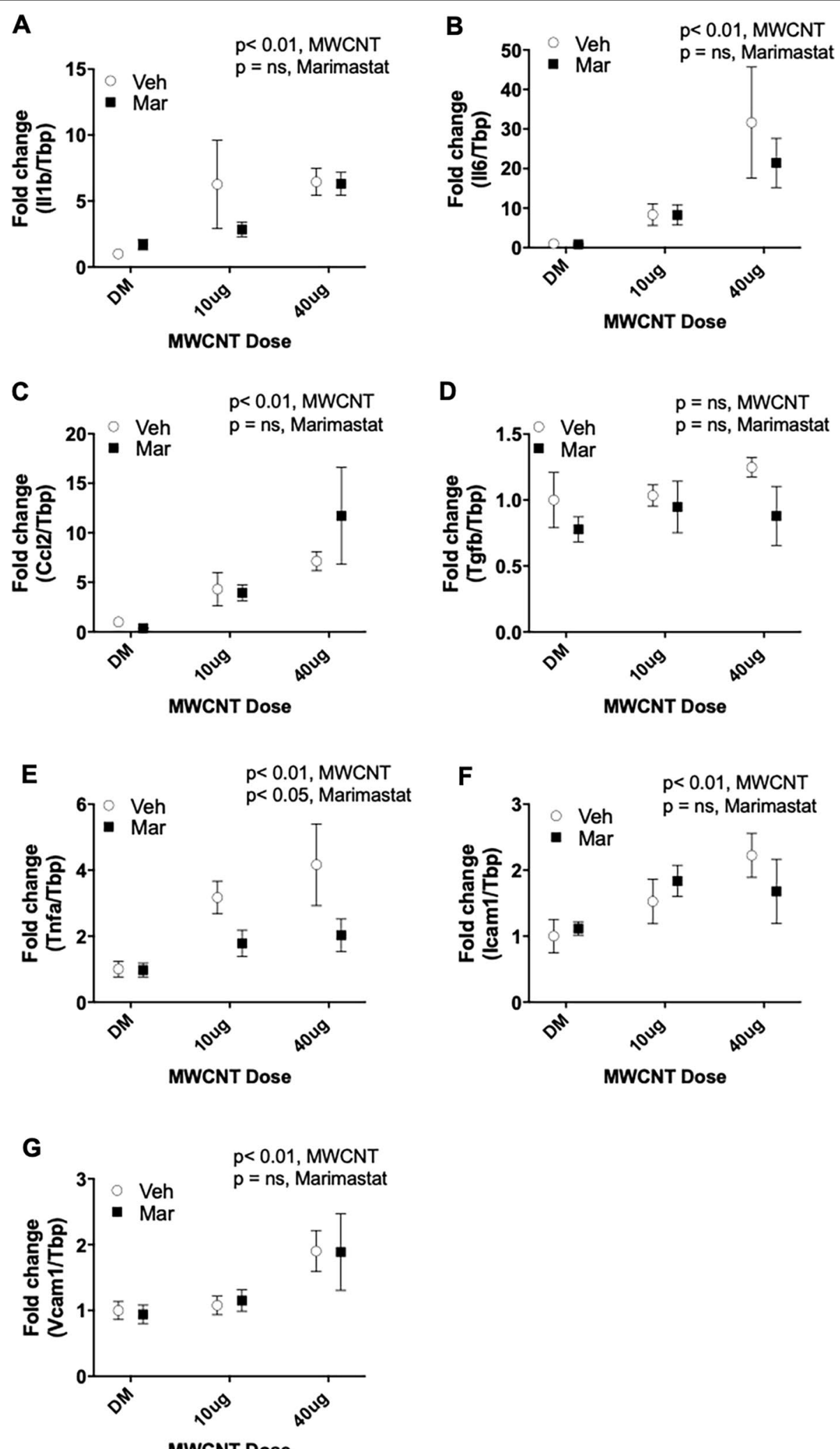

Fig. 5 (See legend on previous page.) 


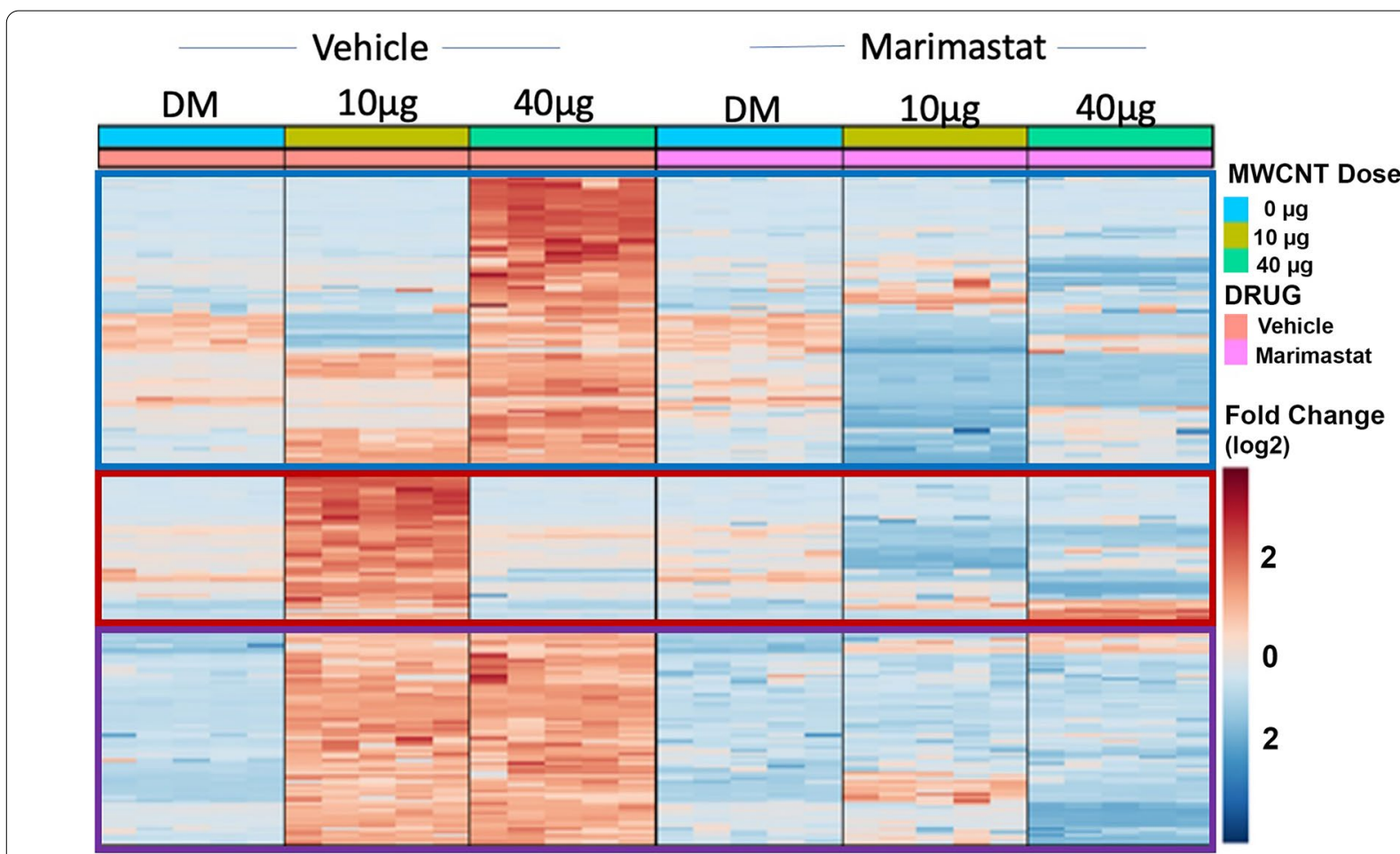

Fig. 6 Serum peptidomics heatmap. MWCNT-induced peptide serum profile changes assessed via Mass Spectrometry. MWCNT exposure increased total serum peptide composition in a differential dose-dependent manner. Left panel: Serum peptide changes resulting from MWCNT exposure. Blue box: Serum peptide composition induced exclusively by high dose $(40 \mu \mathrm{g})$ MWCNT exposure; Red box: Serum peptide composition induced by exclusively low dose $(10 \mu \mathrm{g})$ MWCNT exposure; Purple box: Serum peptide composition induced by both low and high dose MWCNT exposure. Right panel: Serum peptide profile generated by MWCNT and Marimastat exposure. MWCNT-induced serum peptide changes were abrogated by broad spectrum MMP inhibitor, Marimastat. These findings indicate an MMP-mediated mechanism of action for MWCNT in generating lung-derived serum bioactivity. $N=5$ per group

to control levels and was not significantly different from MWCNT alone.

\section{Discussion}

In the present study, we utilized a broad-spectrum MMP inhibitor administered in the lung to demonstrate that: (1) lung MMP activity does not mediate initial MWCNTinduced pulmonary innate inflammation; (2) MWCNTinduced circulating peptides are generated as a result of MMP activity in the lung; and confirms that (3) attendant bioactivity of serum from MWCNT-exposed mice is driven in part by the pulmonary-derived circulating peptides. The pulmonary specific delivery of the MMP inhibitor and acute time frame of the study design, along with the subsequent serum peptide profile changes, infers a pulmonary MMP-mediated mechanism of action for inhaled MWCNT exposures, as has been previously identified with MWCNT and other inhaled pollutants [26, 29] (Fig. 9).

MMPs are elevated in lung pathologies such as pulmonary hypertension, asthma, COPD, pulmonary fibrosis and cancer [42, 43]. Local cells produce MMP-9 when stimulated, and additional generation may occur from immune cells recruited to the lung microenvironment in response to insult; importantly, reactive oxygen species alone can activate constitutive MMPs [44]. Pulmonary oxidative stress is clearly elevated by MWCNT aspiration [45-47]; however, we did not assess the contribution of oxidative stress to the systemic spill-over in this study. The biological pathways underlying nanomaterial-mediated respiratory pathology seem, at least on the surface, to mirror those of air pollution exposures: activation of inflammatory signaling, oxidative stress, enzyme activation and ECM remodeling [47-49]. However the impact of MWCNT inhalation exposure outside the lung, while evident in many studies, remains an incompletely understood phenomenon. The present study therefore suggests that many downstream/extrapulmonary effects of inhaled particulates, such as MWCNT, may be related to pulmonary MMP activation and spillover of fragmented peptides, including matrikines, into the circulation, which in turn drive endothelial inflammatory responses and impair barrier function. 

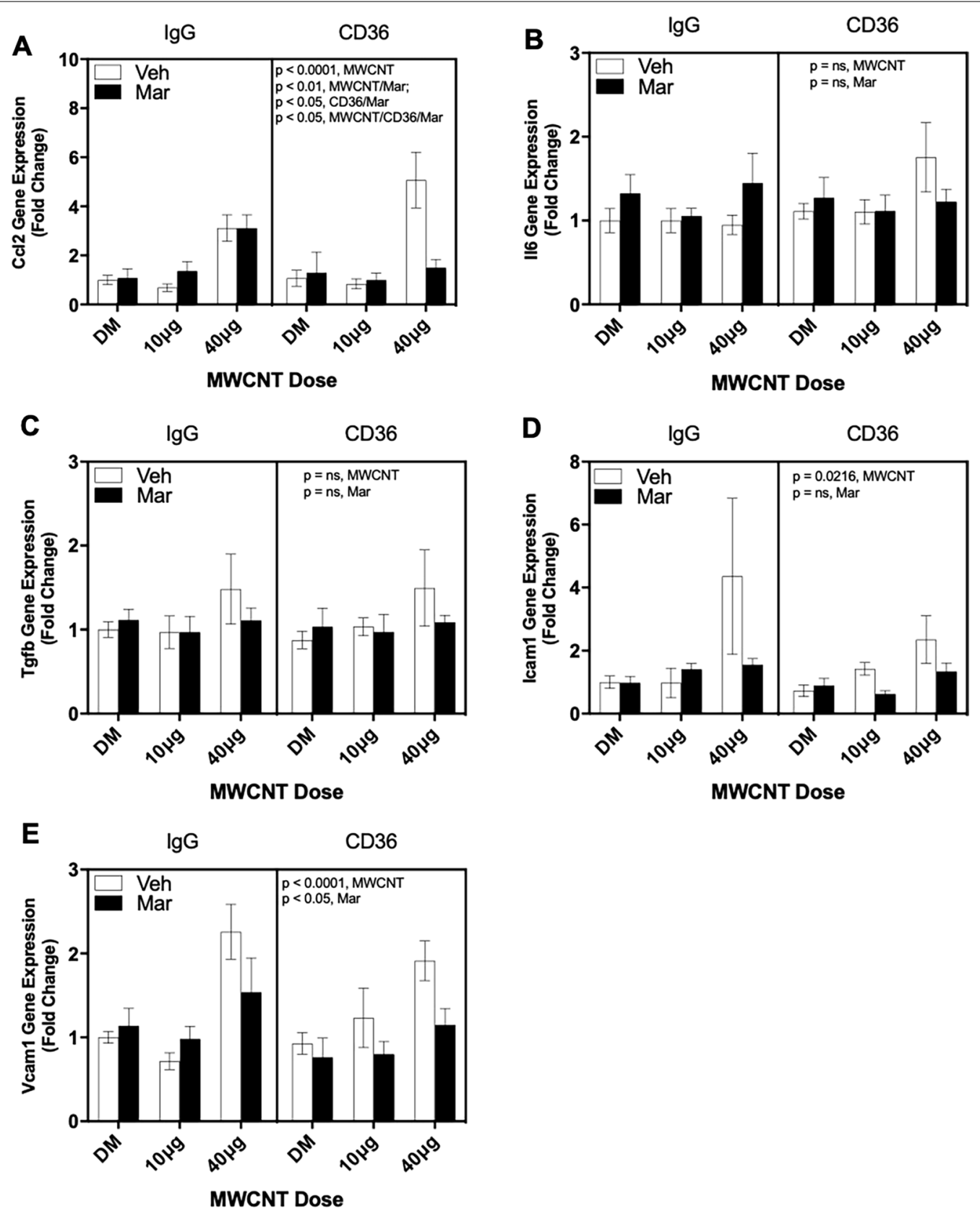

Fig. 7 MWCNT in vitro serum bioactivity evaluation. Contribution of CD36 to MWCNT-mediated serum cumulative inflammatory potential in mouse cerebrovascular endothelial cells (mCEC). Cells in monolayer were treated with a CD36 blocking antibody or lgG control antibody, followed by 5\% v/v serum from C57BL/6 mice exposed to MWCNT in conjunction with MMP blockade. qPCR performed on cell isolates to access cytokine gene expression changes. Shown are gene expression for $\mathbf{a} C \mathrm{Cl}, \mathbf{b} \| 6, \mathbf{c} \mathrm{Tgfb}, \mathbf{d} / \mathrm{cam} 1$, and $\mathbf{e} \mathrm{Vcam} 1 . \mathrm{p}$ values based on 3-way ANOVA presented for each figure. $\mathrm{N}=4-5$ per group. Data presented are means \pm SEM

Research on MWCNT-mediated systemic toxicity has generally focused on vascular [50-53] and immune responses [49, 54-57], however gaps remain in our understanding of how toxic effects move beyond the lung. Our previous work showed a role for MMP-9 and endothelial CD36 in a ligand generating/ligand binding relationship in mediating MWCNT-induced vasomotor impairment [26]. Serum from MMP-9 deficient mice exposed to MWCNT failed to recapitulate the dilatory inhibition induced by serum from wild-type mice treated with MWCNT, providing the first evidence of a possible mechanistic role of MMPs in MWCNT-mediated 




generation of serum bioactivity [26]. Findings by Mandler et al. of a TSP-mediated peripheral microvascular vascular impairment following MWCNT exposure provided further evidence, which narrowed the players in the MWCNT-mediated vascular outcomes [27]. TSP is a widely expressed matrix glycoprotein that has roles as both a substrate of MMP-9 and a ligand for CD36 and CD47. We observed an $\sim 50 \%$ increase in circulating TSP after MWCNT treatment, but more interestingly we identified a 59-mer peptide fragment containing the thrombospondin repeat domain (the region that interacts with CD36), which was elevated $\sim 1000 \%$ over control [29]. Since TSP is not only an important modulator of nitric oxide signaling [58], but also an MMP substrate, this protein and related peptide fragments may reflect an important pathway for systemic effects of pulmonary particulate exposures.

Previously, we showed that vascular CD36 was essential for vasorelaxation impairments induced by serum from ozone-exposed mice [59], in addition to repercussions documented from MWCNT-exposed mouse serum [26]. The implication is that pulmonary MMP-derived circulating peptides may act through cell-surface scavenger or pattern recognition receptors to drive systemic pathology. We have previously shown that MWCNT exposure produces overlapping BALF and serum peptide profiles and composition corresponding to, among others, ECM components and MMP substrates [29]. Additionally, MMP-9 protein levels were shown to be elevated in lung tissue and BALF in these early studies. Although we did not assess MMP levels in the present study, the signifcant findings, observed with targeted MMP blockade, points to changes in either protein or activity levels of these proteases. We hypothesized that the hallmark inflammatory activation and frustrated phagocytosis seen with MWCNT exposures may drive elevated and sustained MMP levels that result in not only lung ECM degradation, but barrier integrity impairments that may result in the release of these degradation products into the systemic circulation. The role of MMPs in lung pathologies have been extensively explored and shown to be important in the inflammatory response to exposures as well as in maintaining vascular homeostasis and regulating vascular permeability [21, 60, 61], which might facilitate the transfer of bioactive fragments into the systemic circulation.

With respect to the bioactivity in serum observed from the MWCNT treatment, we have measured comparable bioactivity in terms of endothelial cell activation, as well as vasomotor alterations, with inhalation of various 


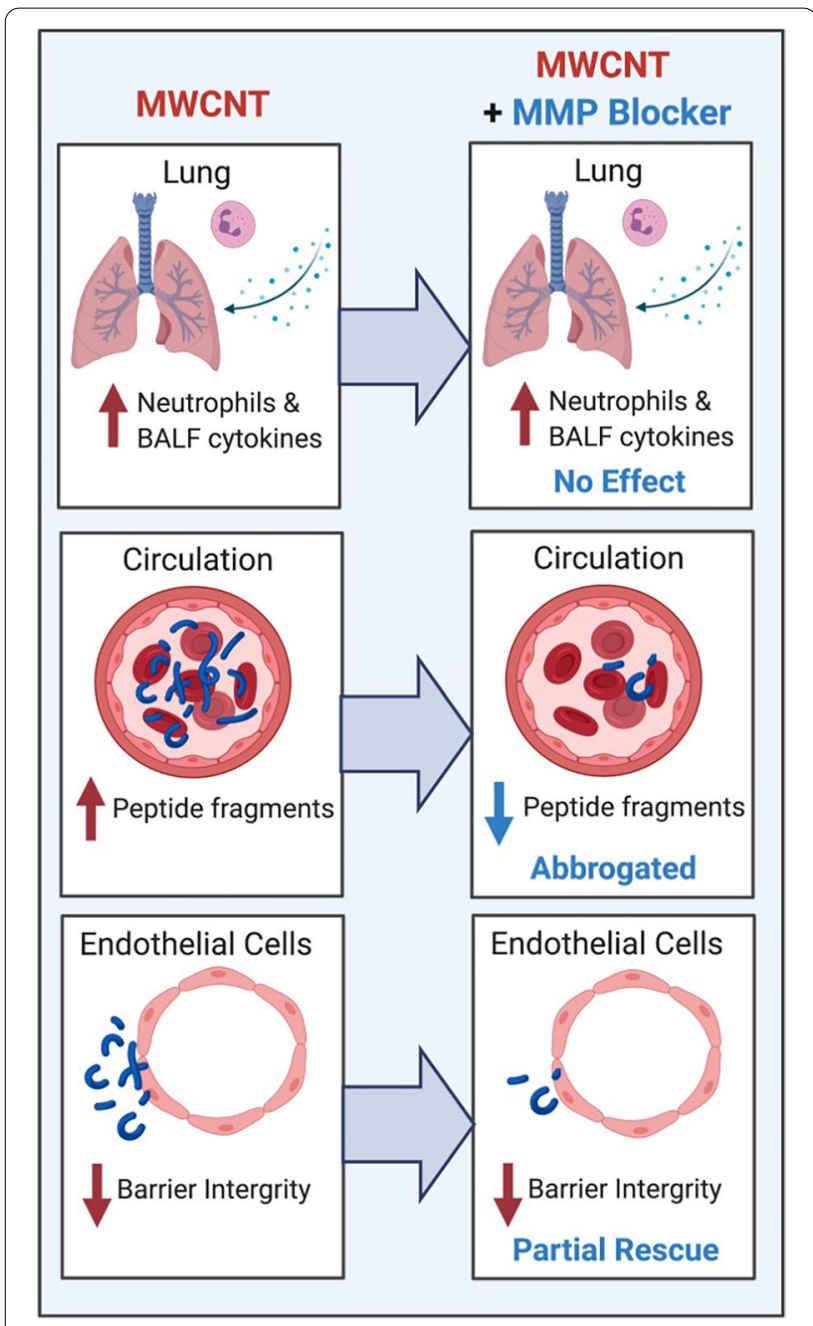

Fig. 9 Graphical Summary. Consequences of MWCNT oropharyngeal exposure in C57BL/6 mice. MWCNT induced pulmonary inflammatory activation as evidenced by increased neutrophilia and dose-dependent cytokine BALF profile and whole lung gene expression. MMP blockade did not play a role in the observed pulmonary findings. However, MMP activity was shown in induce serum peptide profile changes in a dose-dependent differential manner. Administration of broad-spectrum MMP inhibitor Marimastat abrogated these serum changes and return peptide profiles to near unexposed levels. The systemic consequences of these serum changes were evaluated in vitro. Serum from MWCNT exposed mice decreased endothelial barrier integrity as assessed via ECIS. Marimastat treatment, presumably through blockade of MMP activity in the lung, resulted in serum with considerably less potential for endothelial cell activation. These findings provide a mechanism for MWCNT action in the lung and starts to elucidate the systemic consequences of inhalation exposures to MWCNT. Additionally, serum findings provide a base for the exploration of MWCNT exposure and pathological systemic consequences, as well as the identification of biomarkers of both particles and gases at environmentally-relevant concentrations, and notably in human subjects $[9,28,29,62-$ 64]. Circulating bioactivity has also been demonstrated to be a hallmark of several inflammatory clinical syndromes, including atherosclerosis and obstructive sleep apnea [38, 39], and exposure such as cigarette smoking [65]. A recent study by Mostovenko et al. also demonstrated that MWCNT exposure induces peptide changes in cerebrospinal fluid and blood of male C57BL/6 mice which corelate with mechanisms invovled in neuroinflamattion, blood brain barrier disruption and hyperexcitation phenotypes, strengthening the idea of adverse systemic consequnces from pulmonary exposures to MWCNT [40]. Interestingly, of the inflammatory markers used in assessing serum inflammatory bioactivity in this study, MMP blockade reduced only Ccl 2 and Vcam 1 gene levels in endothelial cells exposed to MWCNTexposed mouse serum. This decrease in inflammatory activation in endotherlial was facilitated by the inhibition of CD36 scavenger receptor (Fig. 7a, b). Both Ccl2 and Vcam1 are known to play key role in CD36 signaling and recruitment of inflammtory cells to site of exposure $[66,67]$. Deficiency in CD36 has been shown to be reduce proinflammatory signaling, cell recruitment, $\mathrm{Ccl} 2$ and Vcam1 levels in models of ischemic stroke and atherosclerosis [66, 68, 69]. Thus, the reduction in these genes in our study when CD36 is blocked strengthens the possibility of a CD36 role in mediating some MWCNTinduced systemic outcomes via receptor ligands generated by pulmonary MMP activity. Our study adds depth to the existing attempts to identify blood component changes in relation to respiratory exposures, which tend to center on identification of biomarkers of exposure $[70,71]$ rather than with determining potential systemic impacts of exposure-generated factors.

The findings of serum-borne bioactivity after pulmonary MWCNT treatment must be couched within the limits of the study design. For one, the relevance of bolus dosing by oropharyngeal aspiration in comparison to whole body inhalation continues to be an area of debate. Mercer et al. demonstrated that MWCNT distribution is similar for both methods of exposure, although inflammatory responses are greater with aspiration [72]. In regards to distribution, 1 day after pharyngeal aspiration exposure, $81.6 \%$ and $18 \%$ of the MWCNT lung burden was in the alveolar and airway compartments, respectively [64]. However, we have previously determined that average inhalable elemental carbon concentrations observed in U.S.-based CNT facilities was approximately $10 \mu \mathrm{g} / \mathrm{m}^{3}$, which would equate to roughly $2 \mathrm{ng} / \mathrm{d}$ of nanotube deposition in a mouse [34]. Thus, the doses of 10 and $40 \mu \mathrm{g}$ MWCNT by oropharyngeal aspiration reflects 13 and 55 years of deposition (19 and 76 when you factor 
for a 250 or so work days per year), delivered in a single day. Notably much higher carbon particulate exposures can be observed in countries with less stringent regulations [73]. While deposited MWCNT may have a long persistance in the deep lung, we have not carried out studies to confirm that pulmonary inflammation, MMP activity, formation of bioactive peptides, or vascular responses remained elevated long after exposure. These results which would have relevance for human exposures. Particularly in an occupational setting in the manufacture and incorporation of MWCNT into consumer and industrial products.

\section{Conclusions}

In this inhibition study, we show that pulmonary MWCNT-exposure resulted in the generation of circulating peptide fragments with resultant inflammatory bioactivity in vitro and impairment of endothelial barrier integrity is influenced by lung MMPs. MMP inhibition did not appear to limit the severity of pulmonary inflammation in this context, suggesting that systemic circulatory and vascular effects may be secondary to macrophage activation and pulmonary influx of polymorphonuclear neutrophils. Limitations in the study design prohibit broader interpretation of the results as it relates to the role of pulmonary MMPs for chronic systemic outcomes. However, these data add to the existing literature and help to further define the pathological mechanisms underpinning systemic consequences of pulmonary nanomaterial exposures.

\begin{abstract}
Abbreviations
ANOVA: Analysis of variance; BALF: Bronchoalveolar lavage fluid; CCL2: C-C motif chemokine ligand-2; CD36: Cluster of differentiation 36; CD47: Cluster of differentiation 47; CNT: Carbon nanotube; COPD: Chronic obstructive pulmonary disease; $\mathrm{CT}$ : Cycle threshold; $\mathrm{CxCl1/2}$ : The chemokine (C-X-C motif) ligand 1/2; DMSO: Dimethylsulfoxide; ECIS: Electric cell-substrate impedance sensing; ECM: Extracellular matrix; IACUC: Institutional Animal Care and Use Committees; ICAM1: Intercellular adhesion molecule 1; IFN- $\gamma$ : Interferon gamma; IgG: Immunoglobulin G; IL-10: Interleukin 10; IL-12p70: Interleukin 12 active heterodimer; IL-1 B: Interleukin 1 beta; IL-2: Interleukin 2; IL-4: Interleukin 4; IL-5: Interleukin 5; IL-6: Interleukin 6; KC-GRO: Keratinocyte chemoattractant-human growth-regulated oncogene; Mar: Marimastat; mCEC: Mouse cerebrovascular endothelial cell; MMP: Matrix metallopeptidases; MWCNT: Multi-walled carbon nanotubes; OCT: Optimal cutting temperature; PBS: Phosphate buffered saline; PGP: Pro-gly-pro; PLGS: ProteinLynx Global SERVER ${ }^{\mathrm{TM}}$; SCIP: Serum cumulative inflammatory potential; Tbp: TATA-box binding protein; TGF- $\beta 1$ : Transforming growth factor beta 1; TNF-a: Tumor necrosis factor alpha; Tsp-1: Thrombospondin 1; VCAM: Vascular cell adhesion molecule 1; VEGF: Vascular endothelial growth factor; Veh: Vehicle.
\end{abstract}

\section{Acknowledgements}

Not applicable.

\section{Authors' contributions}

Manuscript writing: TLY, JLD, AE, AKO, MJC; Exposures: TLY, JGB, SNL, GH, KF; Outcome Measurements: TLY, JGB, GH, KZ, RH, RS, TW, EM; Study Design: TLY, $J L D, A E, T W, K Z, E M, A K O, M J C$; Funding: AKO, AE, MJC; All authors have read and approved the final manuscript.

\section{Funding}

The study was funded by the Centers for Disease Control / National Institute for Occupational Health and Safety (R01 OH010828).

\section{Availability of data and materials}

All data related to this study are publicly available upon reasonable request to the corresponding author.

\section{Declarations}

\section{Ethics approval and consent to participate}

Animals were housed in an Association for Assessment and Accreditation of Lab Animal Care International-approved animal facility at the University of New Mexico with procedures approved by Institutional Animal Care and Use Committee of the University of New Mexico. Animal care and use procedures were conducted in accordance with the US Public Health Service's Policy on Humane Care and Use of Laboratory Animals (https://grants.nih.gov/grants/ olaw/references/phspol.htm) and the National Institutes of Health's Guide for the Care and Use of Laboratory Animals (https://grants.nih.gov/grants/olaw/ Guide-for-the-Care-and-Use-of-Laboratory-Animals.pdf).

\section{Consent for publication}

Not applicable.

\section{Competing interests}

The authors declare no conflicts of interest with the content of this manuscript. The findings and conclusions in this report are those of the authors and do not necessarily represent the official position of the National Institute for Occupational Safety and Health, Centers for Disease Control and Prevention.

\section{Author details}

'Department of Pharmaceutical Sciences, MSC09 5360, 1 University of New Mexico, Albuquerque, NM 87131-0001, USA. ${ }^{2}$ Department of Anatomy and Neurobiology, Virginia Commonwealth University, PO Box 980709, Richmond, VA 23298, USA. ${ }^{3}$ College of Nursing, University of New Mexico, Albuquerque, NM 87131, USA. ${ }^{4}$ Department of Internal Medicine, University of Arizona College of Medicine, Phoenix, AZ, USA. ${ }^{5}$ Pathology and Physiology Research Branch, National Institute for Occupational Safety and Health, Morgantown, WV 26505, USA.

Received: 9 April 2021 Accepted: 27 August 2021

Published online: 08 September 2021

\section{References}

1. Bandala ER, Berli M. Engineered nanomaterials (ENMs) and their role at the nexus of food, energy, and water. Mater Sci Energy Technol. 2019;2(1):29-40.

2. Beard JD, Erdely A, Dahm MM, de Perio MA, Birch ME, Evans DE, et al. Carbon nanotube and nanofiber exposure and sputum and blood biomarkers of early effect among U.S. workers. Environ Int. 2018;116:214-28.

3. Bierkandt FS, Leibrock L, Wagener S, Laux P, Luch A. The impact of nanomaterial characteristics on inhalation toxicity. Toxicol Res (Camb). 2018;7(3):321-46.

4. Dahm MM, Schubauer-Berigan MK, Evans DE, Birch ME, Bertke S, Beard $J D$, et al. Exposure assessments for a cross-sectional epidemiologic study of US carbon nanotube and nanofiber workers. Int J Hyg Environ Health. 2018;221(3):429-40

5. Mohanta D, Patnaik S, Sood S, Das N. Carbon nanotubes: evaluation of toxicity at biointerfaces. J Pharm Anal. 2019;9(5):293-300.

6. Helland A, Wick P, Koehler A, Schmid K, Som C. Reviewing the environmental and human health knowledge base of carbon nanotubes. Environ Health Perspect. 2007;115(8):1125-31.

7. Eatemadi A, Daraee H, Karimkhanloo H, Kouhi M, Zarghami N, Akbarzadeh A, et al. Carbon nanotubes: properties, synthesis, purification, and medical applications. Nanoscale Res Lett. 2014;9(1):393.

8. Pattan G, Kaul G. Health hazards associated with nanomaterials. Toxicol Ind Health. 2014;30(6):499-519. 
9. Aragon MJ, Chrobak I, Brower J, Roldan L, Fredenburgh LE, McDonald JD, et al. Inflammatory and vasoactive effects of serum following inhalation of varied complex mixtures. Cardiovasc Toxicol. 2016;16(2):163-71.

10. Kobayashi N, Izumi H, Morimoto Y. Review of toxicity studies of carbon nanotubes. J Occup Health. 2017;59(5):394-407.

11. Kolosnjaj J, Szwarc H, Moussa F. Toxicity studies of carbon nanotubes. Adv Exp Med Biol. 2007:620:181-204.

12. Helland A, Scheringer M, Siegrist M, Kastenholz HG, Wiek A, Scholz RW. Risk assessment of engineered nanomaterials: a survey of industrial approaches. Environ Sci Technol. 2008;42(2):640-6.

13. Ray JL, Holian A. Sex differences in the inflammatory immune response to multi-walled carbon nanotubes and crystalline silica. Inhal Toxicol. 2019;31(7):285-97.

14. Bonnans C, Chou J, Werb Z. Remodelling the extracellular matrix in development and disease. Nat Rev Mol Cell Biol. 2014;15(12):786-801.

15. Chiang TY, Tsao SM, Yeh CB, Yang SF. Matrix metalloproteinases in pneumonia. Clin Chim Acta. 2014;433:272-7.

16. Loffek S, Schilling O, Franzke CW. Series "matrix metalloproteinases in lung health and disease": biological role of matrix metalloproteinases: a critical balance. Eur Respir J. 2011;38(1):191-208.

17. Shimoda M, Khokha R. Metalloproteinases in extracellular vesicles. Biochim Biophys Acta Mol Cell Res. 2017;1864(11 Pt A):1989-2000.

18. Gaggar A, Weathington N. Bioactive extracellular matrix fragments in lung health and disease. J Clin Investig. 2016;126(9):3176-84.

19. Arroyo AG, Iruela-Arispe ML. Extracellular matrix, inflammation, and the angiogenic response. Cardiovasc Res. 2010;86(2):226-35.

20. Weathington $N M$, van Houwelingen $A H$, Noerager $B D$, Jackson $P L$, Kraneveld AD, Galin FS, et al. A novel peptide CXCR ligand derived from extracellular matrix degradation during airway inflammation. Nat Med. 2006;12(3):317-23.

21. Patel DF, Snelgrove RJ. The multifaceted roles of the matrikine Pro-Gly-Pro in pulmonary health and disease. Eur Respir Rev. 2018;27(148):180017.

22. Abdul Roda M, Fernstrand AM, Redegeld FA, Blalock JE, Gaggar A, Folkerts G. The matrikine PGP as a potential biomarker in COPD. Am J Physiol Lung Cell Mol Physiol. 2015;308(11):L1095-101.

23. Wells JM, Gaggar A, Blalock JE. MMP generated matrikines. Matrix Biol. 2015;44-46:122-9.

24. Akthar S, Patel DF, Beale RC, Peiro T, Xu X, Gaggar A, et al. Matrikines are key regulators in modulating the amplitude of lung inflammation in acute pulmonary infection. Nat Commun. 2015;6:8423.

25. Xu X, Jackson PL, Tanner S, Hardison MT, Abdul Roda M, Blalock JE, et al. A self-propagating matrix metalloprotease-9 (MMP-9) dependent cycle of chronic neutrophilic inflammation. PLoS ONE. 2011;6(1):e15781.

26. Aragon M, Erdely A, Bishop L, Salmen R, Weaver J, Liu J, et al. MMP9-dependent serum-borne bioactivity caused by multiwalled carbon nanotube exposure induces vascular dysfunction via the CD36 scavenger receptor. Toxicol Sci. 2016;150(2):488-98.

27. Mandler WK, Nurkiewicz TR, Porter DW, Kelley EE, Olfert IM. Microvascular dysfunction following multiwalled carbon nanotube exposure is mediated by thrombospondin-1 receptor CD47. Toxicol Sci. 2018;165(1):90-9.

28. Aragon MJ, Topper L, Tyler CR, Sanchez B, Zychowski K, Young T, et al. Serum-borne bioactivity caused by pulmonary multiwalled carbon nanotubes induces neuroinflammation via blood-brain barrier impairment. Proc Natl Acad Sci USA. 2017;114(10):E1968-76.

29. Mostovenko E, Young T, Muldoon PP, Bishop L, Canal CG, Vucetic A, et al. Nanoparticle exposure driven circulating bioactive peptidome causes systemic inflammation and vascular dysfunction. Part Fibre Toxicol. 2019;16(1):20

30. Porter DW, Hubbs AF, Chen BT, McKinney W, Mercer RR, Wolfarth MG, et al. Acute pulmonary dose-responses to inhaled multi-walled carbon nanotubes. Nanotoxicology. 2013;7(7):1179-94

31. Porter DW, Hubbs AF, Mercer RR, Wu N, Wolfarth MG, Sriram K, et al. Mouse pulmonary dose- and time course-responses induced by exposure to multi-walled carbon nanotubes. Toxicology. 2010;269(2-3):136-47.

32. Fraser K, Kodali V, Yanamala N, Birch ME, Cena L, Casuccio G, et al. Physicochemical characterization and genotoxicity of the broad class of carbon nanotubes and nanofibers used or produced in U.S. facilities. Part Fibre Toxicol. 2020;17(1):62.

33. Erdely A, Hulderman T, Salmen R, Liston A, Zeidler-Erdely PC, SchweglerBerry D, et al. Cross-talk between lung and systemic circulation during carbon nanotube respiratory exposure. Potential biomarkers. Nano Lett. 2009;9(1):36-43.

34. Erdely A, Dahm M, Chen BT, Zeidler-Erdely PC, Fernback JE, Birch ME, et al. Carbon nanotube dosimetry: from workplace exposure assessment to inhalation toxicology. Part Fibre Toxicol. 2013;10(1):53.

35. Birch ME, Wang C, Fernback JE, Feng HA, Birch QT, Dozier AK. Analysis of carbon nanotubes and nanofibers on mixed cellulose ester filters by transmission electron microscopy in NIOSH manual of analytical methods. 5th ed. London: DHHS Publication; 2017.

36. Distler U, Kuharev J, Navarro P, Tenzer S. Label-free quantification in ion mobility-enhanced data-independent acquisition proteomics. Nat Protoc. 2016;11(4):795-812

37. Cortes DF, Landis MK, Ottens AK. High-capacity peptide-centric platform to decode the proteomic response to brain injury. Electrophoresis. 2012:33(24):3712-9.

38. Cung H, Aragon MJ, Zychowski K, Anderson JR, Nawarskas J, Roldan C, et al. Characterization of a novel endothelial biosensor assay reveals increased cumulative serum inflammatory potential in stabilized coronary artery disease patients. J Transl Med. 2015;13:99.

39. Zychowski KE, Sanchez B, Pedrosa RP, Lorenzi-Filho G, Drager LF, Polotsky VY, et al. Serum from obstructive sleep apnea patients induces inflammatory responses in coronary artery endothelial cells. Atherosclerosis. 2016;254:59-66.

40. Mostovenko E, Saunders S, Muldoon PP, Bishop L, Campen MJ, Erdely A, et al. Carbon nanotube exposure triggers a cerebral peptidomic response: barrier compromise, neuroinflammation, and a hyperexcited state. Toxicol Sci. 2021;182(1):107-19.

41. Mostovenko E, Saunders S, Muldoon PP, Bishop L, Campen MJ, Erdely A, et al. Carbon nanotube exposure triggers a cerebral peptidomic response: barrier compromise, neuroinflammation and a hyperexcited state. Toxicol Sci. 2021;182:107-19.

42. Shvedova AA, Kisin E, Murray AR, Johnson VJ, Gorelik O, Arepalli S, et al. Inhalation vs. aspiration of single-walled carbon nanotubes in C57BL/6 mice: inflammation, fibrosis, oxidative stress, and mutagenesis. Am J Physiol Lung Cell Mol Physiol. 2008;295(4):L552-65.

43. Gueders MM, Foidart JM, Noel A, Cataldo DD. Matrix metalloproteinases (MMPs) and tissue inhibitors of MMPs in the respiratory tract: potential implications in asthma and other lung diseases. Eur J Pharmacol. 2006;533(1-3):133-44.

44. Rajagopalan S, Meng XP, Ramasamy S, Harrison DG, Galis ZS. Reactive oxygen species produced by macrophage-derived foam cells regulate the activity of vascular matrix metalloproteinases in vitro. Implications for atherosclerotic plaque stability. J Clin Investig. 1996;98(11):2572-9.

45. Dong J, Ma Q. Suppression of basal and carbon nanotube-induced oxidative stress, inflammation and fibrosis in mouse lungs by Nrf2. Nanotoxicology. 2016;10(6):699-709.

46. Luyts K, Smulders S, Napierska D, Van Kerckhoven S, Poels K, Scheers H, et al. Pulmonary and hemostatic toxicity of multi-walled carbon nanotubes and zinc oxide nanoparticles after pulmonary exposure in Bmal1 knockout mice. Part Fibre Toxicol. 2014;11:61.

47. Luyts K, Van Den Broucke S, Hemmeryckx B, Poels K, Scheers H, Casas L, et al. Nanoparticles in the lungs of old mice: pulmonary inflammation and oxidative stress without procoagulant effects. Sci Total Environ. 2018;644:907-15

48. Shvedova AA, Pietroiusti A, Fadeel B, Kagan VE. Mechanisms of carbon nanotube-induced toxicity: focus on oxidative stress. Toxicol Appl Pharmacol. 2012;261(2):121-33.

49. Mitchell LA, Gao J, Wal RV, Gigliotti A, Burchiel SW, McDonald JD. Pulmonary and systemic immune response to inhaled multiwalled carbon nanotubes. Toxicol Sci. 2007;100(1):203-14.

50. Vidanapathirana AK, Thompson LC, Odom J, Holland NA, Sumner SJ, Fennell TR, et al. Vascular tissue contractility changes following late gestational exposure to multi-walled carbon nanotubes or their dispersing vehicle in sprague dawley rats. J Nanomed Nanotechnol. 2014;5(3):201.

51. Thompson LC, Holland NA, Snyder RJ, Luo B, Becak DP, Odom JT, et al. Pulmonary instillation of MWCNT increases lung permeability, decreases gp130 expression in the lungs, and initiates cardiovascular IL-6 transsignaling. Am J Physiol Lung Cell Mol Physiol. 2016;310(2):L142-54.

52. Long J, Xiao Y, Liu L, Cao Y. The adverse vascular effects of multi-walled carbon nanotubes (MWCNTs) to human vein endothelial cells (HUVECs) in vitro: role of length of MWCNTs. J Nanobiotechnol. 2017;15(1):80. 
53. Davis G, Lucero J, Fellers C, McDonald JD, Lund AK. The effects of subacute inhaled multi-walled carbon nanotube exposure on signaling pathways associated with cholesterol transport and inflammatory markers in the vasculature of wild-type mice. Toxicol Lett. 2018;296:48-62.

54. Schubauer-Berigan MK, Dahm MM, Toennis CA, Sammons DL, Eye T, Kodali V, et al. Association of occupational exposures with ex vivo functional immune response in workers handling carbon nanotubes and nanofibers. Nanotoxicology. 2020;14(3):404-19.

55. Bishop L, Cena L, Orandle M, Yanamala N, Dahm MM, Birch ME, et al. In vivo toxicity assessment of occupational components of the carbon nanotube life cycle to provide context to potential health effects. ACS Nano. 2017;11(9):8849-63.

56. McPeek M, Malur A, Tokarz DA, Lertpiriyapong K, Gowdy KM, Murray G, et al. Alveolar macrophage ABCG1 deficiency promotes pulmonary granulomatous inflammation. Am J Respir Cell Mol Biol. 2019;61(3):332-40.

57. Hindman B, Ma Q. Carbon nanotubes and crystalline silica stimulate robust ROS production, inflammasome activation, and IL-1 beta secretion in macrophages to induce myofibroblast transformation. Arch Toxicol. 2019;93(4):887-907.

58. Isenberg JS, Frazier WA, Roberts DD. Thrombospondin-1: a physiological regulator of nitric oxide signaling. Cell Mol Life Sci. 2008;65(5):728-42.

59. Robertson S, Colombo ES, Lucas SN, Hall PR, Febbraio M, Paffett ML, et al. CD36 mediates endothelial dysfunction downstream of circulating factors induced by $\mathrm{O} 3$ exposure. Toxicol Sci. 2013;134(2):304-11.

60. Dagouassat M, Lanone S, Boczkowski J. Interaction of matrix metalloproteinases with pulmonary pollutants. Eur Respir J. 2012;39(4):1021-32.

61. Korpos E, Wu C, Sorokin L. Multiple roles of the extracellular matrix in inflammation. Curr Pharm Des. 2009;15(12):1349-57.

62. Channell MM, Paffett ML, Devlin RB, Madden MC, Campen MJ. Circulating factors induce coronary endothelial cell activation following exposure to inhaled diesel exhaust and nitrogen dioxide in humans: evidence from a novel translational in vitro model. Toxicol Sci. 2012;127(1):179-86.

63. Cole E, Ray JL, Bolten S, Hamilton RF Jr, Shaw PK, Postma B, et al. Multiwalled carbon nanotubes of varying size lead to DNA methylation changes that correspond to lung inflammation and injury in a mouse model. Chem Res Toxicol. 2019;32:1545-53.

64. Mercer RR, Hubbs AF, Scabilloni JF, Wang L, Battelli LA, Schwegler-Berry D, et al. Distribution and persistence of pleural penetrations by multi-walled carbon nanotubes. Part Fibre Toxicol. 2010;7:28.
65. Barua RS, Ambrose JA, Eales-Reynolds LJ, DeVoe MC, Zervas JG, Saha DC. Heavy and light cigarette smokers have similar dysfunction of endothelial vasoregulatory activity: an in vivo and in vitro correlation. J Am Coll Cardiol. 2002;39(11):1758-63.

66. Harb D, Bujold K, Febbraio M, Sirois MG, Ong H, Marleau S. The role of the scavenger receptor CD36 in regulating mononuclear phagocyte trafficking to atherosclerotic lesions and vascular inflammation. Cardiovasc Res. 2009;83(1):42-51.

67. Silverstein RL, Li W, Park YM, Rahaman SO. Mechanisms of cell signaling by the scavenger receptor CD36: implications in atherosclerosis and thrombosis. Trans Am Clin Climatol Assoc. 2010;121:206-20.

68. Kim EH, Tolhurst AT, Szeto HH, Cho SH. Targeting CD36-mediated inflammation reduces acute brain injury in transient, but not permanent, ischemic stroke. CNS Neurosci Ther. 2015;21(4):385-91.

69. Kuchibhotla S, Vanegas D, Kennedy DJ, Guy E, Nimako G, Morton RE, et al. Absence of CD36 protects against atherosclerosis in ApoE knock-out mice with no additional protection provided by absence of scavenger receptor A I/II. Cardiovasc Res. 2008;78(1):185-96.

70. Suhaimi NF, Jalaludin J. Biomarker as a research tool in linking exposure to air particles and respiratory health. Biomed Res Int. 2015;2015:962853.

71. Delfino RJ, Staimer N, Vaziri ND. Air pollution and circulating biomarkers of oxidative stress. Air Qual Atmos Health. 2011;4(1):37-52.

72. Mercer RR, Scabilloni J, Wang L, Kisin E, Murray AR, Schwegler-Berry D, et al. Alteration of deposition pattern and pulmonary response as a result of improved dispersion of aspirated single-walled carbon nanotubes in a mouse model. Am J Physiol Lung Cell Mol Physiol. 2008;294(1):L87-97.

73. Tang J, Cheng W, Gao J, Li Y, Yao R, Rothman N, et al. Occupational exposure to carbon black nanoparticles increases inflammatory vascular disease risk: an implication of an ex vivo biosensor assay. Part Fibre Toxicol. 2020;17(1):47.

\section{Publisher's Note}

Springer Nature remains neutral with regard to jurisdictional claims in published maps and institutional affiliations.
Ready to submit your research? Choose BMC and benefit from:

- fast, convenient online submission

- thorough peer review by experienced researchers in your field

- rapid publication on acceptance

- support for research data, including large and complex data types

- gold Open Access which fosters wider collaboration and increased citations

- maximum visibility for your research: over $100 \mathrm{M}$ website views per year

At BMC, research is always in progress.

Learn more biomedcentral.com/submissions 